\title{
INTEGRASI ILMU-ILMU KEISLAMAN DALAM PERSPEKTIF M. AMIN ABDULLAH
}

\author{
Parluhutan Siregar \\ Fakultas Ushuluddin IAIN Sumatera Utara \\ Jl. Willem Iskandar Pasar V Medan Estate, Medan, 20371 \\ e-mail: parluregar@gmail.com
}

\begin{abstract}
Abstrak: Kritik terhadap pola pengembangan ilmu-ilmu Keislaman terutama pada tataran perguruan tinggi agama Islam belakangan ini banyak mendapat perhatian di Indonesia. Tulisan ini merupakan deskripsi-analitis terhadap pemikiran M. Amin Abdullah tentang integrasi ilmu-ilmu Keislaman. Penulis mengemukakan bahwa ilmu-ilmu Keislaman yang berkembang selama ini bersifat fragmentaris dan belum memiliki keterkaitan dengan isu-isu kekinian. Karena itu, diperlukan upaya membangun epistemologi keilmuan integratif-interkonektif. Penulis menemukan bahwa epistemologi keilmuan teo-antropo-sentrik-integralistik Amin Abdullah dibangun dari pengelompokan keilmuan. Teorinya dimulai dari al-Qur'an dan Sunnah, kemudian 'Ulûm al-Dîn, al-Fikr al-Islâmy, dan Dirâsah al-Islâmiyyah. Keempat kategori keilmuan Islam tersebut dipetakan oleh Amin Abdullah ke dalam empat lingkar lapis peta konsep spider web, dengan memadukan seluruh disiplin ilmu sosial dan keagamaan vis-à-vis isuisu kontemporer.
\end{abstract}

\begin{abstract}
The Integration of Islamic Sciences in the Perspective of M. Amin Abdullah. Criticism on the pattern of Islamic sciences development in Indonesia, especially at the level of Islamic religious higher education, has caught the attension of many critiques. This essay tries to analytically describe M. Amin Abdullah's thought who promotes the concept of Islamic sciences integration. The writer maintains that Islamic sciences thus far, have still fragmentary in nature and have not yet interconnected with contemporary issues. As such, it is required to build the epistemology of integrated and interconnected science. The writer finds that theo-anthropocentric-integralistic epistemology of science of Amin Abdullah is developed against the backdrop of classification of science. His theory departs from the Qur'an and Sunnah, 'Ulûm al-Dîn, al-Fikr al-Islâmy, and Dirâsah al-Islâmiyyah. Those categories of Islamic sciences are drawn by Amin Abdullah into four-layered concept mapping of spider web. Such epistemology combines all disciplines of social and religious sciences vis a vis contemporary issues.
\end{abstract}

Kata Kunci: filsafat ilmu, integrasi ilmu, kajian keislaman, M. Amin Abdullah 


\section{Pendahuluan}

Beberapa tahun belakang ini, kritik terhadap pola pengembangan ilmu-ilmu keislaman banyak mendapat perhatian di Indonesia. Salah satu tokoh yang paling serius melakukan kritik itu adalah M. Amin Abdullah (selanjutnya ditulis Amin Abdullah). Dalam sejumlah tulisannya, ia berulang-kali mengkritisi nalar keagamaan yang berkembang di Indonesia, sembari menyuguhkan konsep Studi Agama sebagai sebuah model baru dalam mendekati Islam. Melalui tawaran ini, Amin Abdullah hendak merubah tradisi pengajian agama bercorak normatif-doktriner ke pendekatan studi agama yang bercorak sosio-historis yang dilanjutkan dengan rasional-filosofis.

Amin Abdullah adalah seorang sarjana Muslim Indonesia yang dikenal cukup banyak menulis tentang Islam. Ia memilih tema-tema yang amat beragam, mulai dari Filsafat, 'Ilmu Kalam, Ushul Fiqh, Metode Tafsir Alquran, Pluralisme, sampai masalah Pendidikan. Sepintas lalu, tradisi ini dianggap tidak lazim pada era modern, di mana para ahli konsisten menekuni disiplin ilmu tertentu. Karena itu, kehadiran tulisan yang variatif ini mengundang pertanyaan, "apa sesungguhnya yang menjadi fokus Amin Abdullah? Berdasarkan telaah sementara, sepertnya Amin Abdullah tidak bermaksud untuk menjelajahi semua bidang ilmu, tetapi ia ingin menjalinnya ke dalam satu rangkaian epistemologis yang dipetakannya menjadi semacam "jaring laba-laba".

Teori jaring laba-laba (spider web) yang digagas oleh Amin Abdullah berkaitan dengan horison keilmuan Islam, bukan saja bertujuan untuk mengembangkan kerangka ilmuilmu dasar keislaman yang bersifat normatif, tetapi juga ingin mengintegrasikan-nya dengan ilmu sekular yang bersifat empiris-rasional. Pada aspek inilah daya tarik pemikiran Amin Abdullah, di mana ia mampu merumuskan epistemologi keilmuan yang dapat meramu bermacam-macam ilmu sehingga jelas apa esensi masing-masing disiplin ilmu dan bagaimana cara dan strategi untuk mengembangkannya.

Tulisan ini merupakan upaya menemukan "benang merah" yang mempersatu-kan pikiran-pikiran Amin Abdullah yang berserakan dalam sejumlah buku (yang umumnya berawal dari artikel-artikel lepas) dan makalah-makalah pada berbagai macam diskusi dan seminar. Sumber primer tulisan ini adalah karya-karya Amin Abdullah, baik berupa buku maupun artikel.

\section{Latar Belakang Pemikiran Amin Abdullah}

Jika dilihat secara umum, paling tidak ada dua faktor yang membentuk pemikiran Amin Abdullah dalam konteks keilmuan Islam, yaitu; latar belakang pendidikan dan pekerjaan atau jabatannya. Kedua faktor ini tampaknya saling berkelindan untuk mengantar Amin Abdullah ke tengah barisan tokoh pemikir Islam di Indonesia.

Dari segi pendidikan, sejatinya Amin Abdullah adalah seorang ahli yang mumpuni dalam bidang studi agama-agama dan filsafat. Kesimpulan ini berkaitan dengan riwayat 
pendidikannya sebagai sarjana dari Jurusan Perbandingan Agama Fakulltas Ushuluddin IAIN Sunan Kalijaga Yogyakarta tahun 1982 dan doktor filsafat dari Department of Philosophy, Faculty of Art and Sciences, Middle East Technical University (METU), Ankara, Turki (1990). Seperti yang akan dipaparkan nanti, kedua disiplin ilmu ini merupakan kerangka dasar yang selalu digunakan oleh Amin Abdullah dalam berbagai aspek keilmuan. Karena itu, walaupun sering berbicara pada disiplin lain, seperti tafsir dan pendidikan, Amin Abdullah akan menggunakan filsafat atau metode studi agama sebagai landasan berpikir. Jadi, hampir semua karya tulisnya memiliki keterkaitan dengan studi agama atau filsafat; mungkin dari segi kontennya atau dari segi kerangka berpikirnya.

Selain mengembangkan pemikiran filsafat, Amin Abdullah juga tertarik dengan dialog antaragama. Obsesi untuk mewujudkan dialog antarumat beragama sudah tumbuh pada diri Amin Abdullah sejak memasuki IAIN Sunan Kalijaga dan terus menguat setelah menjadi pejabat di UIN ini. Begitu masuk IAIN di Yogyakarta tahun 1978, Amin merasa kota ini amat kondusif untuk kerukunan hidup beragama. Istilah Amin, "Yogyakarta adalah kota yang unik dan inspirasitif dalam kaitan dialog antar-agama". Semua penganut agama ada di kota ini dan hidup rukun, karena itu layak menjadi sentral dialog tentang multikulturalisme di Indonesia. Keberagaman suku, agama, komunitas, tata perumahan, kultur Jawa yang kental hanya dimiliki Yogyakarta. Dari kenyataan itu, setelah menjadi Rektor, Amin Abdullah pernah menyatakan, bahwa tugas ini menarik sebab ia memiliki pengalaman yang berharga, selain akademik juga administratif. ${ }^{1}$

Profesi sebagai dosen dan kemudian menjadi Guru Besar Filsafat Agama (1999) serta kedudukannya sebagai pejabat di IAIN/UIN Sunan Kalijaga yang cukup lama, mulai dari Asisten Direktur Program Pascasarjana (1992-1995), Pembantu Rektor I Bidang Akademik (1998-2001), dan Rektor (2002-2005 dan 2005-2010), cukup penting dalam membentuk pemikiran Amin Abdullah dalam bidang pendidikan terutama keterpaduan ilmu keislaman dengan ilmu umum. Konversi IAIN Sunan Kalijaga menjadi Universitas Islam Negeri (UIN) ${ }^{2}$, pada masa Amin Abdullah menjabat Rektor, merupakan faktor penting yang banyak menyita pemikirannya untuk berkonsentrasi pada bangunan keilmuan dalam sistem pendidikan di PTAI. Jabatan penting itu menjadi tantangan tersendiri bagi Amin Abdullah untuk menata sistem pengetahuan di PTAI, bukan saja di lingkungan UIN Sunan Kalijaga tetapi seluruh PTAI di Indonesia.

Bertolak dari latar belakang pendidikan dan jabatan tersebut di atas, Amin Abdullah cukup intens mencermati keadaan ilmu-ilmu Keislaman di Indonesia. Seperti lazimnya

${ }^{1}$ ST. Sularto, "Amin Abdullah", dalam http://www.uin-suka.info/ind/index2.php? option= com_content\&do_pdf=1\&id=509, diakses 21 Juli 2010.

${ }^{2}$ Konversi IAIN Sunan Kalijaga menjadi UIN terjadi pada tahun 2004 berdasarkan Keputusan Bersama Menteri Pendidikan dan Menteri Agama Republik Indonesia Nomor: 1/0/SKB/2004; Nomor: ND/B.V/I/Hk.00.1/058/04 tentang Perubahan Bentuk Institut Agama Islam Negeri (IAIN) Sunan Kalijaga menjadi Universitas Islam Negeri (UIN) Sunan Kalijaga Yogyakarta ditandatangani di Departemen Pendidikan Nasional Jakarta pada tanggal 23 Januari 2004. 
tradisi para pembaru yang memulai misinya dari kritik terhadap kondisi obyektif yang sudah mapan, Amin Abdullah banyak mengkritik realitas keberagamaan dan pemahaman agama yang ada pada masyarakat dan PTAI. Aspek utama yang menjadi sorotannya berkisar pada struktur bangunan keilmuan Islam dan keilmuan modern (sekuler). Kondisi-kondisi obyektif yang dikritik oleh Amin ini dapat dikategorikan sebagai faktor penting yang membentuk pola pikir dan ekspresi pemikirannya.

Hal pertama yang dikritisi Amin Abdullah adalah gagasan pembaruan dari para modernis Muslim dari berbagai belahan dunia. Menurut penilaiannya, klaim para pemikir modernis, seperti Abduh, Iqbal, Harun Nasution, dan Sutan Takdir, tentang keterbelakangan umat Islam dan mengusulkan "rasionalisasi" dan "meniru Barat" sebagai solusi untuk menyamai Dunia Barat, tidak seluruhnya menguntungkan umat Islam. Gagasan tersebut ternyata, selain tidak menyelesaikan persoalan, justru yang terjadi adalah menguatnya pandangan atas superioritas bangsa Barat dan inferioritas bangsa Timur, khususnya umat Islam. Lebih jauh, pandangan tersebut telah membentuk sikap menyesali dunianya dan agamanya. Jadi, cita-cita untuk menyaingi dunia Barat malah berefek menguatkan Barat. ${ }^{3}$

Aspek lain yang disoroti Amin Abdullah adalah bangunan keilmuan Islam yang sudah mengakar di kalangan akademisi Perguruan Tinggi Agama Islam (PTAI). Ia merasakan keluhan masyarakat terhadap alumni PTAI yang hanya mengetahui soal-soal "normatifitas" agama sendiri, tetapi kesulitan memahami historisitasnya, apalagi historisitas agama orang lain. Kenyataan ini berkaitan dengan persoalan pokok tentang titik perpaduan antara "ilmu" dan "agama". Bangunan keilmuan yang diajarkan di PTAI masih mengikuti model single entity atau isolated entities, dan belum mau menerima atau belum mampu menerapkan model interconnected entities. ${ }^{4}$ Pada level praksis, mahasiswa dan dosen pada bidang natural sciences tidak mengenal isu-isu dasar social-sciences, dan humanities dan lebih-lebih religious studies dan begitu sebaliknya. Keterpisahan ini hanya akan mencetak ilmuan dan praktisi yang tidak berkarakter. Indonesia dan dunia ketiga pada umumnya yang mengikuti begitu saja pola keilmuan tersebut tanpa modifikasi, sehingga menggiring ke arah krisis multidimensional sejak dari lingkungan hidup, ekonomi, politik, sosial, agama, moral yang ber-

${ }^{3}$ Amin Abudllah, Islamic Studies di Perguruan Tinggi: Pendekatan Integratif-Interkonektif (Yogyakarta: Pustaka Pelajar, 2006), h. 5-6.

${ }^{4}$ Amin Abdullah menjelaskan bahwa model single entity adalah pengetahuan agama yang berdiri sendiri tanpa memerlukan bantuan metodologi yang digunakan oleh ilmu pengetahuan umum; selanjutnya model isolated entities berarti masing-masing rumpun ilmu berdiri sendiri, tahu keberadaan rumpun ilmu yang lain tetapi tidak bersentuhan dan tegur sapa secara metodologis; sedangkan model interconnected entities, adalah bangunan ilmu yang masing-masing sadar akan keterbatasannya dalam memecahkan persoalan manusia, lalu menjalin kerjasama setidaknya dalam hal yang menyentuh persoalan pendekatan (approach) dan metode berpikir dan penelitian (process dan procedure). Lihat; Amin Abdullah, "Islam dan Modernisasi Pendidikan di Asia Tenggara: Dari Pola Pendekatan Dikotomis-atomistik kearah integratif-interdisiplinary", Makalah disampaikan dalam Konferensi Internasional Antar Bangsa Asia Tenggara, Universitas Gadjah Mada, Yogyakarta, 10-11 Desember 2004. 
kepanjangan. Karenanya, jangan-jangan sistem pendidikan yang berjalan selama ini memang punya andil secara tidak langsung terbentuknya split of personality (kepribadian terpecah). ${ }^{5}$

Bertolak dari penilaian di atas, Amin meragukan kemampuan metodologis dosendosen PTAI yang mengajarkan ilmu-ilmu keislaman. Ada kemungkinan mereka mengajarkan cabang-cabang keilmuan Islamic Studies (Dirasat Islamiyyah), yang mungkin saja sudah mendetail, tetapi terlepas begitu saja dan kurang begitu memahami asumsi-asumsi dasar dan kerangka teori yang digunakan oleh bangunan keilmuan tersebut serta implikasi dan konsekwensinya pada wilayah praksis sosial-keagamaan. Keraguan itu menguat atas kemampuan para dosen untuk melakukan perbandingan antara berbagai sistem epistemologi pemikiran keagamaan Islam dan melakukan auto-kritik terhadap bangunan keilmuan yang diajarkan. Belum lagi kemampuan menghu-bungkan asumsi dasar, kerangka teori, paradigma, metodologi serta epistemologi yang dimiliki oleh satu disiplin ilmu dan disiplin ilmu yang lain untuk memperluas horizon dan cakrawala analisis keilmuan.

Dalam kenyataan di lapangan, agak sulit diperoleh jawaban mengapa dosen-dosen yang mengajarkan Islamic Studies atau 'Ulûm ad-Dîn (Kalam, Fiqh, Falsafah Islam, Nahwu, Balaghah, Ulum al-Qur'an, Ulum al Hadis, Tasawuf, juga Pendidikan dan Dakwah) di PTAI kurang begitu tertarik untuk memahami asumsi dasar, kerangka teori, paradigma, epistemologi, cara kerja dan struktur fundamental keilmuan yang melatar-belakangi dibangunnya ilmu-ilmu tersebut. Salah satu jawaban yang paling mudah diperoleh di antaranya adalah oleh karena belum banyak penelitian dan buku yang disusun khusus untuk wilayah kajian tersebut. Sedang jawaban IAIN yang dapat diduga lebih umum dijumpai adalah bahwa wilayah filsafat dan epistemologi keilmuan Islamic Studies atau 'Ulûm ad-Dîn memang sengaja dihindari pembahasannya, karena wilayah yang lebih bersifat "konseptual-fiosofis" (pure sciences). Pembahasan ini lebih rumit dan lebih pelik daripada pembahasan dan pengajaran ilmu-ilmu praktis yang telah "jadi” dan "mapan" dan tinggal mempraktikkan dalam kehidupan sehari-hari. Bukan rahasia lagi bahwa diskusi falsafah pada umumnya, apalagi filsafat ilmu sangat dihindari oleh para fuqahâ dan mutakallimun karena dianggap akan membingungkan umat. Keadaan menipisnya-untuk tidak mengatakan menghilangnyakesadaran historisitas pemikiran keislaman, menurut Amin Abdullah menyulitkan para pemikir Muslim kapan pun dan di mana pun mereka berada untuk berijtihad secara mandiri.

Amin Abdullah masih merasakan adanya kecurigaan terhadap filsafat. Fakta ini merupakan problem tersendiri, karena selain akan terus memelihara dikotomi Ilmu Agama dengan Ilmu Umum, ia juga akan berdampak pada pembentukan pemikiran umat Islam Indonesia. Dari keadaan itu, secara otomatis dan alami terjadi proses kekeringan dan bahkan pengeringan sumber mata air dinamika keilmuan keislaman yang merupakan jantung dan prasyarat bagi pengembangan keilmuan Islamic Studies dan 'Ulûm ad-Dîn, khususnya dalam menghadapi tantangan-tantangan baru yang muncul ke permukaan. Pada gilirannya, hal ini meng-

${ }^{5}$ Ibid. 
akibatkan "terpencilnya" Islamic Studies dan 'Ulûm ad-Dîn dari wilayah pergaulan keilmuan dan sulitnya upaya pengembangan wilayah (contribution to knowledge) bagi Islamic Studies atau Dirasat Islamiyyah itu sendiri. ${ }^{6}$

Lebih jauh Amin Abdullah menyoroti epistemologi keilmuan Islam klasik yang tersimpul pada epistemologibayânî, 'irfani dan burhani. ${ }^{7}$ Menurutnya, ketiga kluster sistem epistemologi 'Ulûmuddîn ini masih berada dalam satu rumpun, tetapi dalam praktiknya hampir-hampir tidak pernah seiring-sejalan. Pola pikir tekstual bayânî lebih dominan dari dua lainnya dan secara hegemonik membentuk mainstream pemikiran keislaman. Akibatnya, pola pemikiran keagamaan Islam menjadi kaku. Otoritas teks dan otoritas salaf yang dibakukan dalam kaidah-kaidah metodologi usul fikih klasik lebih diunggulkan dari pada sumber otoritas keilmuan yang lain seperti ilmu-ilmu kealaman (kauniyyah), akal (aqliyyah) dan intuisi (wijdaniyyah). Dominasi pola pikir bayânî yang bersifat tekstual-ijtihâdiyyah menjadikan sistem epistemologi keagamaan Islam kurang begitu peduli terhadap isu-isu keagamaan yang bersifat kontekstual-bahtsiyyah. ${ }^{8}$

Kelemahan epistemologi bayânî atau tradisi berpikir tekstual-keagamaan adalah ketika ia harus berhadapan dengan teks-teks keagamaan yang dimiliki oleh komunitas, kultur, bangsa atau masyarakat beragama lain. Dalam berhadapan dengan komunitas lain agama, corak argumen berpikir keagamaan model tekstual-bayânî biasanya mengambil sikap mental yang bersifat dogmatik, defensif, apologis, dan polemis. Itulah jenis pengetahuan keagamaan yang biasa disebut sebagai al-'ilm al-tauqîfí. Pola berpikir inilah, menurut Amin Abdullah -dengan meminjam istilah Muhammed Arkoun, yang menimbulkan sikap penyakralan pemikiran keagamaan (taqdis al-afkar al-diniyyah). Akibatnya, hanya lantaran perbedaan kerangka teori, metodologi, epistemologi serta variasi dan kedalaman literatur yang digunakan, umat Islam mudah sekali saling murtad-memurtadkan bahkan saling kafir mengkafirkan. Hal demikian dapat saja terjadi karena fungsi dan peran akal pikiran hanyalah digunakan untuk mengukuhkan dan membenarkan otoritas teks. Epistemologi

${ }^{6}$ Amin Abdullah, "Pengembangan Metode Studi Islam dalam Perspektif Hermeneutika Sosial dan Budaya" dalam Jurnal Tarjih edisi ke-6, Juli 2003, (LPPI-UMY dan Majelis Tarjih \& PPI PP Muhammadiyah).

${ }^{7}$ Mohammed Abed Al-Jabiri (asal Maroko) dalam bukunya Post Tradisionalisme Islam (terjemahan), mengemukakan tiga konsep pemikiran Islam. Pertama, bayani, yaitu pemahaman secara tekstual-normatif. Nalar bayani ini lebih terpaku pada teks atau pada dasar-dasar (dikenal dengan sebutan al-ushûl al-arba'ah: al-Quran, sunnah, ijma' dan qiyas) yang dipatok sebagai sesuatu yang baku dan tidak berubah. Kedua, irfani (spiritual-intuitif), yaitu disiplin gnotisisme yang didasarkan pada wahyu dan "pandangan dalam" dengan memasukkan sufisme, pemikiran Syi'i, penafsiran esoterik terhadap al-Qur'an, dan orientasi filsafat illuminasi. Ketiga, burhani, yaitu suatu penalaran rasional-demontsratif yang yang didasarkan atas pada metode epistemologi melalui observasi empiris dan inferensiasi intelektual. Lihat; Muhammad Abed Al Jabiri, Post Tradisionalisme Islam (Yogyakarta: LKiS, 2000), h. xiv-xvii.

${ }^{8}$ Amin Abdullah, Islam dan Modernisasi, h. 6. 
bayani tidak mencermati pelaksanaan dan implementasi ajaran teks dalam kehidupan masyarakat luas apakah masih seoirisinal dan seotentik lafal teks itu sendiri atau tidak. ${ }^{9}$

Pada aspek lain, Amin Abdullah juga mengkritik ilmu-ilmu sekuler. Selama ini para cerdik pandai telah tertipu atas klaim obyektifitas teori-teori modern. Ilmu-ilmu sekuler yang mengklaim sebagai value free (bebas dari nilai dan kepentingan) ternyata penuh muatan kepentingan. Kepentingan itu antara lain ialah dominasi kepentingan ekonomi (seperti sejarah ekspansi negara-negara kuat era globalisasi), dan kepentingan militer/ perang (seperti ilmu-ilmu nuklir), dominasi kepentingan kebudayaan Barat (Orientalisme). ${ }^{10}$ Lebih tegas dinyatakan, bahwa pada era post positivistik, tidak ada satu bangunan keilmuan dalam wilayah apapun yang terlepas sama sekali dari persoalan-persoalan kultural, sosial dan bahkan sosial politik yang melatarbelakangi munculnya, disusunnya dan bekerjanya sebuah paradigma keilmuan.

Sejalan dengan paparan di atas, Moh. Dahlan, dosen Pascasarjana IAIN Sunan Ampel, menyimpulkan, bahwa permasalahan mendasar yang ditemukan oleh Amin Abdullah adalah pendekatan kajian Islam yang bercorak doktrinal-dogmatik dan empiris-positivistik. Pendekatan ini telah memengaruhi corak keberagamaan orang-orang di Indonesia, khususnya pendekatan kajian agama (Islam), dan pola hubungan antaragama di Indonesia, sehingga pola keberagamaannya menjadi bersifat konfliktual, baik secara psikis maupun fisik, baik pada tataran konseptual maupun praksis. Dari kenyatan ini, Amin Abdullah melihat bahwa umat beragama dihadapkan pada pilihan problematik. Atas dasar itu, ia menilai perlunya melakukan rekonstruksi pendekatan kajian agama (Islam) dalam rangka menjawab tantangan pluralitas agama. ${ }^{11}$

\section{Bangunan Keilmuan Teoantroposentris-Integralistik}

Gagasan besar Amin Abdullah terpusat pada bangunan keilmuan yang berwatak teoantroposentris-integralistik. Bangunan keilmuan semacam ini erat kaitannya dengan paradigma filosofis. Menurut Amin Abdullah, ilmu apapun yang disusun tidak bisa tidak mempunyai paradigma kefilsafatan. Asumsi dasar seorang ilmuan merupakan hal pokok yang terkait dengan struktur fundamental yang melekat pada bangunan sebuah bangunan keilmuan, tanpa terkecuali, baik ilmu-ilmu kealaman, ilmu-ilmu sosial, humaniora, ilmuilmu agama ('Ulûm ad-Dîn), studi agama (religious studies) maupun ilmu-ilmu keislaman. Dengan demikian, tidak ada sebuah ilmu pun-lebih-lebih yang telah tersistimatisasikan sedemikian rupa-yang tidak memiliki struktur fundamental yang dapat mengarahkan dan

${ }^{9}$ Amin Abdullah, Falsafah Kalam di Era Postmodernisme (Yogyakarta: Pustaka Pelajar, 1995), h. 19.

${ }^{10}$ Amin Abdullah, Profil Kompetensi, h. 13.

${ }^{11}$ Moh. Dahlan, "Gagasan Islam Kontemporer Menurut M. Amin Abdullah", http:// drdahlan. blogspot.com/2009/08/gagasan-islam-kontemporer-menurut-m.html, diakses 25 Agustus 2009. 
menggerakkan kerangka kerja teoritik maupun praksis keilmuan serta membimbing arah penelitian dan pengembangan lebih lanjut. Struktur fundamental yang mendasari, melatarbelakangi dan mendorong kegiatan praksis keilmuan adalah yang dimaksud dengan filsafat ilmu. ${ }^{12}$

Kedudukan filsafat ilmu begitu urgen dalam pemikiran Amin Abdullah, sehingga ia menjadikannya sebagai obyek kajian dan pembahasannya selama tujuh tahun. Hasilnya ia menerbitkan buku Islamic Studies di Perguruan Tinggi Pendekatan Integratif-Interkonektif. Buku ini menawarkan paradigma interkoneksitas ilmu, suatu pemikiran yang lebih modest (mampu mengukur kemampuan diri sendiri), humbility (rendah hati) dan humanity (manusiawi). Paradigma interkoneksitas berasumsi bahwa untuk memahami kompleksitas kehidupan yang dihadapi dan dijalani manusia, setiap bangunan keilmuan apapun, tidak dapat berdiri sendiri. ${ }^{13}$

Sejalan dengan kritik Amin Abdullah terhadap ilmu-ilmu sekuler dan ilmu-ilmu agama yang disebutnya sedang terjangkit krisis relevansi, sekarang ini menjadi keniscayaan untuk melakukan gerakan rapproachment (kesediaan untuk saling menerima keberadaan yang lain dengan lapang dada) antara dua kubu keilmuan. Gerakan rapproachment atau gerakan integrasi epistemologi keilmuan adalah sesuatu yang mutlak diperlukan untuk mengantisipasi perkembangan-perkembangan yang serba kompleks dan tak terduga. ${ }^{14}$ Lebih jauh, Amin menyatakan, bahwa dalam diskursus keagamaan kontemporer agama mempunyai banyak wajah (multifaces), bukan lagi berwajah tunggal. Agama tidak lagi dipahami sebagai hal yang semata-mata terkait dengan persoalan ketuhanan, kepercayaan, credo, pandangan hidup, dan ultimate concern. Selain sifat konvensionalnya, tenyata agama juga terkait-erat dengan dengan persoalan-persoalan historis-kultural. ${ }^{15}$

Ide integrasi ilmu muncul pada diri Amin Abdullah setelah menelaah pikiran Richard C. Martin, seorang ahli studi keislaman dari Arizona University, dalam bukunya Approaches to Islam in Religious Studies dan pemikiran Muhammed Arkoun -dari Sorbonne, Parisdalam bukunya Tarikhikhiyyah al-Fikr al-'Araby aI-Islâmy juga Nasr Hamid Abu Zaid

${ }^{12}$ Amin Abdullah, "Profil Kompetensi Akademik Lulusan Program Pascasarjana Perguruan Tinggi Agama Islam Dalam Era Masyarakat Berubah", Makalah disampaikan dalam Pertemuan dan Konsultasi Direktur Program Pasca Sarjana Perguruan Tinggi Agama Islam, Hotel Setiabudi, Jakarta, 24-25 Nopember 2002, h. 6-7.

${ }^{13}$ Amin Abudllah, Islamic Studies, h. viii.

${ }^{14}$ Amin Abdullah, "Integrasi Epistemologi Keilmuan Umum dan Agama dalam Sistem Sekolah dan Madrasah (Ke Arah Rumusan Baru Filsafat Pendidikan Islam yang Integralistik)", Makalah dalam "Roundtable discussion tentang Madrasah" diselenggarakan oleh Indonesian Institute for Civil Society (INCIS), Hotel Atlet Century Park Senayan, Jakarta, 22 Juli 2004; http:// aminabd.wordpress.com/2010/04/30/integrasi-epistemologi-keilmuan-umum-dan-agama-dalamsistem-sekolah-dan-madrasah/, diakses 30 April 2010.

${ }^{15}$ Amin Abdullah, "Relevansi Studi Agama-agama dalam Milenium Ketiga," dalam Amin Abdullah (et al.), Mencari Islam: Studi Islam dengan Berbagai Pendekatan (Yogyakarta: Tiarawacana, 2000), h. 2. 
dari Mesir dalam bukunya Naqd al-Khitab al-Diniy. Ketiga sarjana ini dengan tegas ingin membuka kemungkinan kontak dan pertemuan langsung antara tradisi berpikir keilmuan dalam Islamic Studies secara konvensional atau apa yang disebut oleh Imam Abu Hamid al-Ghazzali sebagai 'Ulûm ad-Dîn pada abad ke-10-11 dan tradisi berpikir keilmuan dalam Religious Studies kontemporer yang telah memanfaatkan kerangka teori dan metodologi yang digunakan oleh ilmu-ilmu sosial dan humanities yang berkembang sekitar abad ke18 dan 19. Dialog dan pertemuan antara keduanya telah mulai dirintis oleh ilmuan-ilmuan muslim kontemporer.

Tentu saja, mempertemukan dua tradisi pola pikir keilmuan akan berimplikasi pada filosofinya. Di sini, kerangka teori, metode dan epistemologi yang digunakan pun perlu berubah. Prasyarat utama yang harus dipenuhi untuk membangun keilmuan yang integratif adalah filsafat ilmu yang spesifik, yang tidak lagi murni mengacu pada epistemologi 'Ulûm ad-Dîn dan tidak pula epistemologi ilmu sekular. Implikasi langsung dari perubahan ini adalah peniscayaan adanya paradigma baru sebagai hal yang sangat pokok dan memiliki kedudukan yang vital dalam wilayah kerja keilmuan. Jika Islamic Studies adalah bangunan keilmuan biasa, karena ia disusun dan dirumuskan oleh ilmuan agama (ulama, fuqaha, mutakallimûn, mutasawwifûn, mufassirûn, muhadditsûn) pada era terdahulu sesuai tuntutan zamannya, maka tidak ada alasan untuk menghindarkan diri dari pertemuan, perbincangan dan pergumulannya dengan telaah filsafat ilmu, sesuai dengan tuntutan zaman ini. Dari kerangka berpikir di atas, Amin Abdullah merumuskan bangunan keilmuan yang berwatak teoantroposentris-integralistik, lalu muncullah horison keilmuan dalam bentuk skema jaring laba-laba (lihat gambar di bawah). Inti dari gagasan ini adalah, bahwa; (1) struktur keilmuan membedakan tingkat abstraksi ilmu, mulai dari pure science sampai applied sceince, di mana satu sama lain saling terkait-erat; dan (2) tidak ada pemisahan antara ilmu-ilmu Islam dengan ilmu-ilmu sekuler, sebab keduanya telah menyatu.

Berikut ini akan dianalisis horison jaring laba-laba keilmuan yang digagas oleh Amin Abdullah dilihat dari makna skema, konten dan hubungan antara satu-sama lain. Dengan paparan ini diharapkan ada pemahaman yang tepat mengenai gagasan Amin Abdullah tentang bangunan keilmuan yang diharapkan pada saat ini dan masa akan datang.

Horizon Jaring Laba-laba Keilmuan Teoantroposentris-Integralistik ${ }^{16}$

${ }^{16}$ Amin Abdullah, Islamic Studies, h. 104-105. 


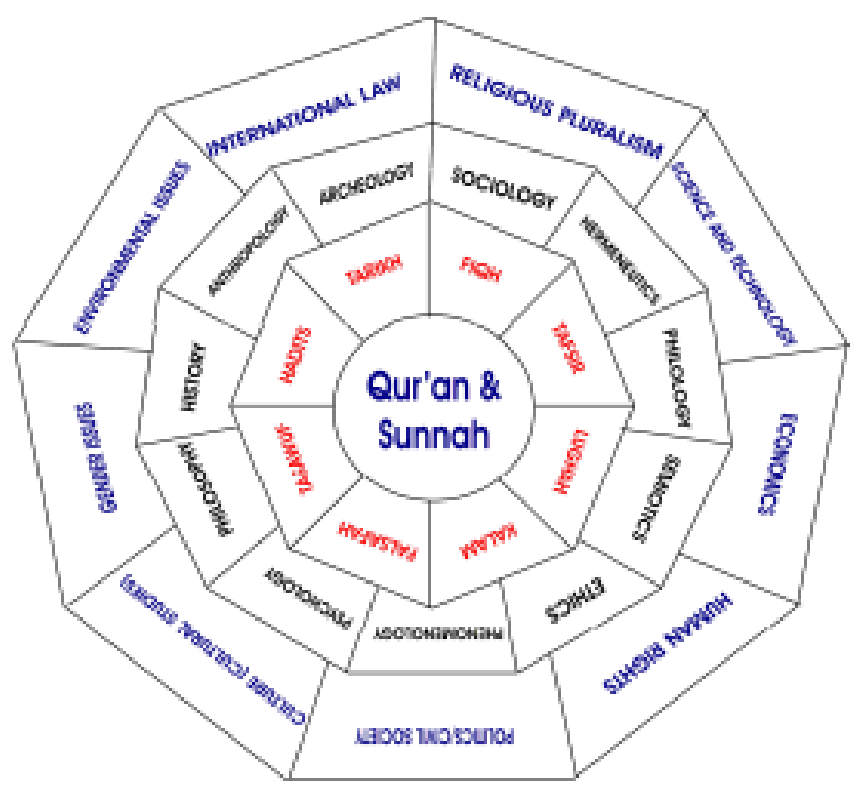

Pada awalnya, spider web adalah suatu strategi pembelajaran yang sengaja dirancang untuk memudahkan transfer pengetahuan dan pengalaman kepada anak didik. Umumnya strategi ini diterapkan dalam sekolah atau pembelajaran outbound. Pada konteks ini, metode spider web menawarkan strategi pembelajaran yang mengintegrasi-kan suatu tema ke dalam semua mata pelajaran. Dalam kegiatan belajar outbound (sekolah alam), semua objek pembelajaran di alam dapat dikaitkan dalam satu tema yang nantinya akan dijabarkan dalam mata pelajaran yang akan digunakan, sedangkan dalam pembelajaran konseptual, metode ini menghasilkan suatu peta konsep. Ciri terpenting dari peta konsep spider web itu adalah tidak menurut hirarki, kecuali berada dalam suatu kategori; dan kategorinya tidak paralel. ${ }^{17}$

Merujuk pengertian di atas, horison spider web yang ditawarkan Amin Abdullah adalah bersifat peta konsep. Sebagai sebuah peta konsep spider web, tentu saja peta ini dapat dimaknai sebagai berikut; (1) bahwa setiap item yang terdapat dalam peta itu memiliki hubungan-hubungan, walau tidak seluruhnya, antara yang satu dengan yang lain; inilah yang dimaksud Amin Abdullah dengan keilmuan integratif; (2) keilmuan itu berpusat pada al-Qur'an dan Sunnah dan secara hirarkis berkaitan dengan sejumlah pengetahuan sesuai dengan tingkat abstraksi dan applied-nya; (3) item-item yang terdapat dalam satu lapis lingkar menunjukkan kesetaraan dilihat dari tingkat abstraksi atau teoritisnya; dan (4) garis-garis yang memisah antara satu item dengan item lain dalam satu lapis lingkar tidak dapat dipahami sebagai garis pemisah.

Seperti yang terlihat dalam gambar, konten jaring laba-laba keilmuan ini tediri

${ }^{17}$ Anwar Kholil, "Peta Konsep untuk Mempermudah Konsep Sulit dalam Pembela-jar-an”, http://anwarholil.blogspot.com/2008/04/peta-konsep-untuk-mempermudah-konsep.html, diakses 7 April 2008. 
atas 4 lapis lingkaran; tiga di antaranya membentuk jalur. Lingkar lapis 1 (paling dalam) adalah Alquran dan Sunnah yang berkedudukan sebagai sumber utama pengetahuan Islam. Di atas lingkar lapis 1 terdapat lingkar lapis 2 yang membentuk jalur dan memuat 8 disiplin ilmu-ilmu Ushuluddin, yaitu Kalam, Falsafah, Tasawuf, Hadits, Tarikh, Fiqh, Tafsir, dan Lughah. Lingkar lapis ke-3 adalah jalur pengetahuan teoritik yang terdiri atas; Sociology, Hermeneutics, Philology, Semiotics, Ethics, Phenomenology, Psychology, Philosophy, History, Antrophology, dan Archeology. Sedangkan lingkar lapis 4 (terluar) merupakan jalur pengetahuan aplikatif, yang terdiri atas; Isu-isu Religious Pluralism, Sciences and Technology, Economics, Human Rights, Politics/Civil Society, Cultural Studies, Gender Issues, Environmental Issues, dan Internastional Law.

Menurut Amin Abdullah, gambar jaring laba-laba keilmuan di atas mengilustrasikan hubungan yang bercorak teoantroposentris-integralistik. Di situ tergambar bahwa jarak pandang dan horizon keilmuan integralistik begitu luas (tidak myopic) sekaligus terampil dalam perikehidupan sektor tradisional maupun modern lantaran dikuasainya salah satu ilmu dasar dan keterampilan yang dapat menopang kehidupan era informasi-globalisasi. Di samping itu tergambar sosok yang terampil dalam menangani dan menganalisis isuisu yang menyentuh kemanusiaan dan keagamaan era modern dan pasca modern dengan dikuasainya berbagai pendekatan baru yang diberikan oleh ilmu-ilmu alam, ilmu-ilmu sosial dan humaniora kontemporer. Di atas segalanya, dalam setiap langkah yang ditempuh, selalu dibarengi landasan etika-moral keagamaan yang objektif dan kokoh, karena keberadaan al-Qur'an dan Sunnah yang dimaknai secara baru (hermeneutis) selalu menjadi landasan pijak pandangan hidup (weltanschauung) keagamaan manusia yang menyatu dalam satu tarikan nafas keilmuan dan keagamaan. Kesemuanya diabdikan untuk kesejahteraan manusia secara bersama-sama tanpa pandang latar belakang etnisitas, agama, ras maupun golongan. ${ }^{18}$

Struktur keilmuan yang digagas ini mengacu pada tradisi keilmuan Islam yang membedakan disiplin kepada tiga kategori, yaitu; 'Ulûm ad-Dîn (Religious Knowledge), al-Fikr al-Islâmiy (Islamic Thought) dan Dirasat Islâmiyyah (Islamic Studies). Pengertian "Ulûm ad-Dîn adalah representasi "tradisi lokal" keislaman yang berbasis pada "bahasa" dan "teks-teks" atau nash-nash keagamaan; selanjutnya al-Fikr al-Islamiy adalah representasi pergumulan humanitas pemikiran keislaman yang berbasis pada "rasio-intelek", sedangkan Dirasat Islamiyyah atau Islamic Studies adalah kluster keilmuan baru yang berbasis pada paradigma keilmuan sosial kritis-komparatif yang melibatkan seluruh "pengalaman" (experiences) umat manusia. ${ }^{19}$

${ }^{18}$ Amin Abdullah, Profil Kompetensi, h. 14.

${ }^{19}$ Amin Abdullah, "Mempertautkan 'Ulûm ad-Dîn, al-Fikr Al-Islamiy dan Dirasat Islam-iyyah: Sumbangan Keilmuan Islam Untuk Peradaban Global", http://aminabd.wordpress.com/ 2010/ 06/20/mempertautkan-ulum-al-diin-al-fikr-al-islamiy-dan-dirasat-islamiyyah-sumbangan-keilmuanislam-untuk-peradaban-global/, diakses 20 Juni 2010. 
Dalam pemahaman Amin Abdullah, Dirasat Islamiyyah atau Islamic Studies sebenarnya berbeda dari pengertian 'Ulûm ad-Dîn yang biasa dikenal selama ini. Ketika disebut 'Ulûm ad-Dîn (Religious Knowledge), umumnya melahirkan pemahaman yang langsung merujuk kepada ilmu-ilmu agama (Islam) seperti aqidah dan syarî'ah dengan menggunakan ilmu bantu bahasa dan logika deduktif yang merujuk dan menderivasi hukum-hukum agama dari kitab suci. Dari sana lalu muncul kluster ilmu-ilmu agama (Islam) seperti Kalâm, Fikih, Tafsir, Hadis, Qur'an, Farâidl, Aqîdah, Akhlâq, Ibadah dan begitu seterusnya dengan ilmu bantunya bahasa Arab (Nahwu, Saraf, Balaghah, Badi', 'Arudl). Dalam perkembangannya, ketika bahan dasar atau bahan pokok (Ushuluddin) keagamaan Islam ini terkumpul dan disusun secara sistematis dan terstruktur secara akademis dengan melibatkan pendekatan sejarah pemikiran (Origin, Change dan Development), maka secara akademik 'Ulûm adDîn berkembang menjadi subjek yang secara luas dikenal di lingkungan PTAI sebagai al-Fikr Islamiy (Pemikiran Islam). ${ }^{20}$

Dengan mengutip Fazlur Rahman dan Abdullah Saeed, ${ }^{21}$ Amin Abdullah mengungkapkan bahwa Islamic Thought atau al-Fikr al-Islâmiy mempunyai struktur ilmu dan the body of knowledge yang kokoh dan komprehensif-utuh tentang Islam, sedang 'Ulûm ad-Dîn seringkali hanya menekankan atau memilih bagian tertentu saja atau satu-dua saja dari the body of knowledge tentang Islam yang utuh-komprehesif tersebut. Kadang penekanannya hanya pada pemikiran Kalam saja dengan meninggalkan kajian Filsafat, pada fikih dengan meninggalkan tasawuf, atau pada Hadis dengan tidak mengenal perdebatan dan pergumulan tentang Hadis. Tidak jarang pula terjadi reduksi dengan hanya memilih salah satu corak pemikiran atau pola pikir 'keilmuan' yang sesuai dengan 'kepentingan' kelompok masingmasing. ${ }^{22}$

Satu hal yang menarik dari teori spider web keilmuan ini adalah penempatan alQur'an di tengah kompleksitas perkembangan keilmuan. Ini suatu penegasan yang penting bagi setiap Muslim, sebab al-Qur'an itu diyakini sebagai sumber kebenaran, etika, hukum, kebijaksanaan, dan pengetahuan. Sekalipun demikian, Amin Abdullah menegaskan, Islam tidak pernah menjadikan wahyu Tuhan sebagai satu-satunya sumber pengetahuan dan melupakan Tuhan. Menurut pandangan ini, sumber pengetahuan itu dua macam, yaitu yang berasal dari Tuhan dan yang berasal dari manusia. Perpaduan antara keduanya itulah yang disebut teoantroposentrisme. Perpaduan itu sekaligus merefleksikan semangat dediferernsiasi. Dengan merujuk Kuntowijoyo, Amin Abdullah menyatakan bahwa modernisme yang menekankan diferensiasi dalam berbagai bidang kehidupan sudah tidak sesuai

${ }^{20}$ Ibid.

${ }^{21}$ Amin Abdullah mencatat, buku Fazlurrahman berjudul Islam dan buku Abdullah Saeed, Islamic Thought: An Introduction (2006), berisi secara komprehensif tentang Studi al-Qur'an dan Sunnah, pemikiran Hukum (Legal thought), pemikiran Kalamiyyah (Theological thought), pemikiran Mistik (Mystical thought atau Sufism), Ekspresi Artistik, pemikiran Filsafat (Philosophical thought), pemikiran politik (Political thought), dan pemikiran Modern dalam Islam.

${ }^{22}$ Ibid. 
lagi dengan semangat zaman. Dalam konteks posmodern dan upaya membangun keilmuan, perlu sekali adanya gerakan resakralisasi, deprivatisasi agama dan ujungnya adalah dediferensiasi (rujuk kembali). Kalau diferensiasi menghendaki pemisahan antara agama dan sektor-sektor kehidupan lain, maka dediferensiasi inilah penyatuan kembali agama dengan sektor-sektor kehidupan lain, termasuk agama dan ilmu.

Paradigma keilmuan baru yang yang digagas Amin Abdullah ini bersifat menyatukan, bukan sekedar menggabungkan, wahyu Tuhan dan temuan pikiran manusia (ilmu-ilmu holistik-integralistik). Penyatuan seperti ini tidak akan berakibat mengecilkan peran Tuhan (sekularisme) atau mengucilkan manusia sehingga teralienasi dari dirinya sendiri, dari masyarakat sekitar, dan lingkungan hidup sekitarnya. Dengan demikian, konsep integralisme dan reintegrasi epistemologi keilmuan ini sekaligus akan dapat menyelesaikan konflik antar sekularisme ekstrim dan fundamentalisme negatif agama-agama yang kaku dan radikal dalam banyak hal. ${ }^{23}$

Teori spider web-nya Amin Abdullah ${ }^{24}$ dapat pula dijadikan rujukan akademis bagi upaya pengembangan sains di masa depan yang juga mendapatkan dukungan teologis dari agama (baca: Islam). Dalam teori ini digambarkan bahwa horizon jaring laba-laba keilmuan agama Islam dalam era masyarakat berubah, mengandaikan bahwa pada periode pertama (pra 1950-an) Islamic Studies masih bersifat eksklusif (hanya mengedepankan pengajaran 'Ulûm ad-Dîn, fiqh, kalam (teologi), tafsir dan hadis (lima bidang kajian). Maka periode kedua (1951-1975) di samping Islamic Studies sebagai core, namun sudah mulai berkenalan -walau masih jalan sendiri-sendiri atau belum ada dialektika antar wilayah ilmu- dengan wilayah kajian humaniora, social sciences dan natural sciences. Sedangkan periode ketiga (1976-1995) wilayah Islamic Studies berkembang menjadi delapan bidang'Ulûm ad-Dîn, fiqh, dan lain-lain- di mana periode ketiga ini juga disebut sebagai era auxiliary sciences. Lalu pada periode keempat (1996-sekarang) core sciencies of Islamic Studies yang delapan bidang tersebut sudah mulai berdialektika dengan wilayah sains dan teknologi (al-'ulûm al-kauniyyah/natural sciences) maupun wilayah kajian lainnya (humaniora dan social sciences). ${ }^{25}$

Sehubungan dengan lingkar lapis tiga spider web keilmuan, Amin Abdullah mencoba menjawab keraguan berberapa pihak tentang kemungkinan membangun disiplin ilmiah, seperti Antropologi, Sosiologi, dan Psikologi, yang dapat menghasilkan teori-teori. Pertanyaan-nya adalah, apakah Islam dapat ditelaah secara ilmiah? Jika yang dimaksudkan Islam di sini adalah "perilaku" individu, "tradisi" masyarakat (turats) -baik dalam dimensi politik, falsafah, ekonomi, sosial-budaya -yang terinspirasikan oleh ajaran Islam, mengapa tidak? Jika yang ditelaah dan diteliti adalah aspek historisitas-kekhalifahan manusia Muslim, mengapa

${ }^{23}$ Amin Abdullah, Profil Kompetensi, h. 13.

${ }^{24}$ Amin Abdullah, Pengembangan Metode, h. 12-18.

${ }^{25}$ Muhammad Azhar, "Wacana Agama dan Sains Dalam Perspektif Epistemologi Keilmuan Islam Kontemporer", http://kangdim.wordpress.com/2009/05/, diakses 26 Mei 2009. 
tidak bisa dibenarkan? ${ }^{26}$ Dalam kaitan ini, Amin Abdullah menambahkan, bahwa agama tidak lagi terbatas hanya sekedar menerangkan hubungan antara manusia dengan Tuhan, tetapi juga melibatkan kesadaran berkelompok (Sosiologis), kesadaran pencarian asalusul agama (Antropologis), pemenuhan kebutuhan untuk membentuk kepribadian yang kuat dan ketenangan jiwa (Psikologis), bahkan ajaran agama tertentu dapat dileiti sejauh mana keterkaitan ajaran etiknya dengan corak pandangan hidup yang memberi dorongan yang kuat untuk memperoleh derajat kesejahteraan hidup (Ekonomi). ${ }^{27}$

Lebih jauh, Amin Abdullah menerangkan beberapa fungsi pengetahuan yang disebut pada lingkar lapis tiga di atas sebagai body dan metode atau pendekatan pengetahuan. Menurut Amin Abdullah filsafat dapat diartikan dengan: pertama, sebagai aliran atau hasil pemikiran, yakni berupa sistem pemikiran yang konsisten dan dalam taraf tertentu sebagai sistem tertutup (closed system). Kedua, sebagai metode berpikir, yang dapat dicirikan mencari ide dasar yang bersifat fundamental (fundamental ideas), membentuk cara berpikir kritis (critical thought), dan menjunjung tinggi kebebasan serta keterbukaan intelektual (intelectual freedom). Jadi, dapat dikatakan bahwa Filsafat adalah pengetahuan metodis, sistematis dan koheren tentang seluruh kenyataan (realitas). Filsafat merupakan refleksi rasional (pikir) atas keseluruhan realitas untuk mencapai hakikat (kebenaran) dan memperoleh hikmat (kebijaksanaan). ${ }^{28}$ Status pendekatan yang terdapat pada lingkar lapis spider web di atas, menurut Amin Abdullah, tidak lepas dari kemampuan manusia-sebagai peniciptanya-untuk menerapkannya.

\section{Analisis terhadap Pemikiran Amin Abdullah}

Pemikiran Amin Abdullah tentang epistemologi keilmuan teoantroposentris-integralistik sesungguhnya tidaklah sama sekali baru. Seperti yang sudah diutarakan di atas, pemikiran beberapa sarjana sebelumnya banyak mengilhaminya. Jika ditelusuri ke belakang pemikiran epistemologis Amin Abdullah memiliki kaitan dengan pemikir-pemikir muslim kontemporer, seperti Fazlur Rahman, Mohammed Arkoun, dan Kunto-wijoyo, serta dengan pemikirpemikir lainnya dari dunia Barat, seperti Thomas Kuhn, Derrida, dan sebagainya. Keterkaitan gagasan Amin Abdullah dengan pemikiran Kunto-wijoyo, misalnya, diakui sendiri oleh Amin Abdullah. Dalam salah satu tulisannya, Amin Abdullah pernah mengungkapkan; "dengan meminjam konsep yang pernah dikembangkan oleh Kuntowijoyo, penulis melanjutkan konsep tersebut dengan sedikit memberi beberapa ilustrasi tambahan di sana sini dalam konteks studi keislaman yang berkembang selama ini di IAIN dan upaya pengembangannya

\footnotetext{
${ }^{26}$ Amin Abdullah, Falsafah Kalam, h. 23.

${ }^{27}$ Amin Abdullah, Studi Agama; Normativitas atau Historisitas? (Yogyakarta: Pustaka Pelajar, 1996), h. 10.

${ }^{28}$ Husain Insawan, "Membedah Esai Pemikiran M. Amin Abdullah", http:// shaututtarbiyah. wordpress.com/2009/11/20/membedah-esai-pemikiran-m-amin-abdul-lah-ed-21-2009/, diakses 20 November, 2009.
} 
lebih lanjut secara integratif di masa depan". Hal ini dapat dilihat dari gagasan dan konsepkonsep yang digunakan Amin Abdullah. Gagasan integralisasi ilmu yang bercorak teoantroposentris, misalnya, adalah gagasan Kuntowijoyo yang kemudian digunakan oleh Amin Abdullah. Demikian juga konsep dediferensiasi dan obyektifikasi dipinjam Amin Abdullah dari gagasan Kuntowijoyo.

Pemikiran Barat yang digunakan Amin Abdullah dalam merumuskan pemikiran-nya bisa dirunut kepada Thomas Kuhn dan Derrida. Menguatnya ide perumusan epistemologi keilmuan Islam tentu saja tidak dapat dikesampingkan terori pengetahuan Thomas Kuhn yang melihat perlunya paradigma baru pengetahuan. Demikian juga teori penafsiran teks dengan pendekatan hermeneutika sudah pasti terilhami oleh beberapa tokoh hermeneutik, seperti Derrida dan Habermas. Implikasi dari pemikiran tersebut adalah studi keislaman merupakan proses progress, dan tidak pernah mengalami sebuah bentuk stagnansi. Semua bentuk pemikiran keagamaan tidak pernah bersih dari konteks historis, sehingga diperlukan penyesuaian terus-menerus. Dalam menafsirkan sebuah teks keagamaan, yang diperlukan adalah sikap terbuka, kritis dan toleran terhadap pemikiran keagamaan lain. ${ }^{29}$

Kalaupun pemikiran epistemologi Amin Abdullah banyak diambil dari sarjana sebelumnya, namun menurut kesimpulan Moh. Dahlan, gagasan Amin Abdullah melampaui tiga model pemikiran di era modern. Jika di era ini tumbuh pemikiran Islam fundamentalis, pemikiran Islam konservatif, dan pemikiran Islam modern, maka gagasan Abdullah melampauinya di mana ia menawarkan pendekatan interconnected entities. Gagasan ini menjawab dua problem kamanusiaan sekaligus, yaitu bidang rekonstruksi pendekatan kajian agama (Islam) maupun bidang rekonstruksi pola hubungan antaragama. Karena itu, teori spider web keilmuan dari Amin Abdullah adalah sebuah prestasi yang layak diapresiasi dan perlu dikembangkan ke depan.

Persoalannya kemudian adalah pada tataran metodologis. Jika diikuti lapis-lapis lingkar spider web yang dipetakan oleh Amin Abdullah, maka akan muncul pertanyaan; "Bagaimana cara menerjemahkan teks-teks wahyu menjadi pemikiran (al-Fikr al-Islâmy), dan bagaimana pula mentransfer pemikiran itu menjadi teori, serta selanjutnya bagaimana menjabarkan-nya sehingga dapat menjawab isu-isu kontemporer"? Jawaban terhadap pertanyaan-pertanyaan ini tentu tidak ditemukan pada pemikiran epistemologis Amin Abdullah, karena ia hanya berbicara pada level filosofis. Tugas para peneliti dan pemikir teknis lah menjabarkan pemikiran filosofis tersebut ke dalam aturan-aturan metodologis.

Hal lain yang belum terjelaskan secara tegas oleh Amin Abdullah dalam epistemologi spider web ini adalah tentang hubungan-hubungan antara konsep-konsep yang terdapat pada lingkar 1, 2, 3, dan 4. Belum didapatkan, misalnya, bagaimana hubungan antara al-Qur'an (lingkar 1) dengan Sosiologi (lingkar 3) kemudian ke Religious Pluralism (lingkar 4). Demikian juga hubungan al-Qur'an dengan konsep-konsep keilmuan lainnya. Ketidak- 
jelasan itu berkaitan dengan banyak hal, seperti sumber pengetahuan, penjabaran dari konsep yang satu pada konsep lainnya, pendekatan dan metode yang digunakan, dan sebagainya. Tentu saja, keadaan ini dapat dimaklumi, karena Amin Abdullah baru berbicara pada level filosofis yang harus dijabarkan lebih rinci dan konkrit lagi ke dalam konteks metodologis.

Bagaimanapun juga, harus diakui bahwa Amin Abdullah telah menyumbang gagasan penting dalam pembaruan pemikiran keislaman di Indonesia. Sumbangan itu berpusat pada usaha meletakkan dasar-dasar konstruksi keilmuan yang mengintegrasikan pemikiran agama yang bersifat normatif dengan pemikiran yang bersifat historis atau yang disebut dengan pendekatan interconnected entities. Dalam kerangka ini, ada yang menarik untuk dikritisi lebih dalam ke depan dari gagasan Amin Abdullah: Pertama, kitab suci (termasuk al-Qur'an dan Sunnah) perlu dipandang sebagai kebenaran yang berlapis-lapis. Kedua, kebenaran yang ada dalam kitab suci perlu dilihat dari berbebagai sudut pandang berbagai keilmuan, sehingga ajaran agama yang berlapis-lapis tersebut bisa diketahui dan dipahami dalam dunia kontemporer. Ketiga, adanya interaksi kitab suci dengan kenyataan historis pada waktu penurunannya yang tidak bisa ditutup-tutupi telah memberikan warna terhadap corak ajaran kitab suci. Ini menandakan bahwa kitab suci janganlah hanya dipandang sebagai murni bersifat ketuhanan, tetapi juga perlu dilihat sebagai realitas historis yang sama dengan produk budaya lainnya. Karenanya pembacaan dengan berbagai dispilin keilmuan dibutuhkan untuk membongkar pendekatan keagamaan yang doktrinal-dogmatik atau historis-empiris. ${ }^{30}$ Keempat, kita perlu membangun kembali secara sistematis dan ekstensif paham keagamaan di dunia kontemporer dengan tidak hanya mencukupkan diri belajar dari agama sendiri, tetapi juga perlu berdialog dengan agama lain, serta perkembangan ilmu-ilmu pengetahuan lainnya. ${ }^{31}$ Dengan kasadaran seperti ini, Amin Abdullah berusaha untuk tidak memitoskan atau menyakralkan produk-produk penafsiran masa lalu, yang kadang-kadang sudah tidak relevan lagi dengan semangat zaman sekarang. Bahkan tafsir masa Nabi dan sahabat adalah sebuah corak tafsir yang baik pada saat itu, tetapi itu tidak menutup kemungkinan belakangan akan mengalami sebuah perubahan akibat adanya perubahan situasi dan kondisi yang terus berjalan. Sebab bagaimanapun, problem, lokalitas, situasi budaya dan kultur yang dihadapi Nabi dan para sahabat juga ikut mewarnai model dan corak tafsirannya dalam memahami al-Qur'an ketika itu, yang sudah barang tentu berbeda dengan problem, tantangan, situasi dan kultur yang kita hadapi sekarang. ${ }^{32}$

\footnotetext{
${ }^{30}$ Amin Abdullah, Studi Agama, h. 61-77, 121-135.

${ }^{31}$ Amin Abdullah, "Agama Masa Depan: Intersubjektif dan Post-Dogmatik", dalam Majalah Basis, nomor 05-06, Tahun Ke-51, Mei-Juni 2002, h. 56.

${ }^{32}$ Amin Abdullah, "Kata Pengantar", dalam Abdul Mustaqim, Madzahibut Tafsir, Peta Metodologi Penafsiran Al-Qur'an Periode Klasik Hingga Kontemporer (Yogyakarta: Nun Pustaka, 2003), h. xixii.
} 


\section{Relevansi Pemikiran Bangunan Keilmuan Amin Abdullah}

Tidak berlebihan bila dikatakan, setelah Harun Nasution, Amin Abdullah adalah tokoh pemikir paling serius yang banyak berbicara tentang pembaruan kurikulum pendidikan di Perguruan Tinggi Agama Islam (PTAI). Jika Harun Nasution berhasil merubah kerangka keilmuan Islam yang diajarkan di PTAI dari pendekatan normatif-doktrinal ke multipendekatan (Islam Ditinjau dari Berbagai Apseknya), maka Amin Abdullah berusaha melanjutkannya dengan pendekatan studi agama yang lebih luas lagi. Pendekatan ini tidak lagi sekedar mengkaji Islam dari berbagai disiplin ilmu, tetapi juga mengkaji Islam untuk melahirkan berbagai disiplin ilmu yang bercorak filosofis, teoretis dan praksis.

Sesungguhnya gagasan Amin Abdullah ini termasuk dalam arus besar pemikiran Islamisasi Sains, tetapi kerangka berpikir yang berbeda. Hal ini bermakna bahwa ide dan gagasan integrasi ilmu yang ditawarkan Amin Abdullah, bukan hanya relevan tetapi juga aktual, karena sejak 30 tahun terakhir ini tema "Islamisasi Ilmu" menjadi wacana yang banyak diperbincangkan di seluruh dunia Islam, termasuk Indonesia. Walaupun sudah banyak ragam pemikiran yang muncul mengenai Islamisasi Ilmu, namun pemikiran Amin Abdullah masih dapat dikatakan memiliki ciri tersendiri sebagai pembeda dari pemikiran lainnya.

Dalam kaitan dengan ciri pemikiran Amin Abdullah tersebut, Moh. Dahlan, dari Pascasarjana IAIN Sunan Ampel, melihat bahwa pemikiran "Islamiasasi" yang dikemas-nya dalam gagasan rekonstruksi pendekatan kajian agama, pada dasarnya mengacu pada dua dari empat pendekatan Ian G. Barbour, tentang alternatif interaksi agama dan sains. Dua pendekatan dimaksud adalah pendekatan dialog dan pendekatan integrasi. Pendekatan dialog banyak digunakan oleh Amin Abdullah sebagai upaya membangun sikap sensitifkritis di antara domain agama dan sains; pendekatan ini dianggap bermanfaat sebagai pengantar ketika domain agama (normatifitas) dan domain histories-empiris (sains) berupaya mencari jati diri sebagai wujud distansiasi. Sedang pendekatan integrasi banyak digunakan oleh Amin Abdullah ketika upaya rekonstruksi pendekatan kajian agama telah sampai pada tahap pengolahan dan pencetusan model baru di dalam pendekatan kajian agama. Dari sini, dapat menyebut rekonstruksi pendekatan kajian agama Amin Abdullah sebagai pola pendekatan dialog-integratif.

Relevansi lain yang tidak kurang pentingnya adalah dari segi pendekatan yang digunakan. Gagasan rekonstruksi pendekatan kajian agama memiliki titik kemajuan dengan munculnya pendekatan interdisipliner dan sekaligus pendekatan multireligius. Pendekatan ini telah memperluas kajian, tidak saja pada penataan hubungan agama dengan sains, seperti yang banyak diwacanakan para ahli Islamisasi Ilmu, tetapi penelaahan hubungan antargama. Pemikiran ini menaawarkan pentingnya mendialogkan dan mengintegrasikan dua hal sekaligus, yaitu agama dengan sains, dan agama yang satu dengan agama yang lainnya. Jika ide ini dapat dikembangkan dan dijabarkan ke dalam strategi-strategi yang lebih aplikatif, maka sudah barang tentu akan menghasilkan pikiran-pikiran atau teoriteori baru yang melampaui atau berbeda dari temuan-temuan sebelumnya. 
Pemikiran tentang bangunan keilmuan yang teoantriposentris-integralistik, seperti yang dirumuskan Amin Abdullah, tentu sudah banyak didiskusikan dalam perumusan kurikulum di PTAI. Sebagai seorang Pembantu Rektor dan kemudian menjadi Rektor di IAIN/UIN lokomotif di Indonesia, pikiran-pikiran dari Amin Abdullah pasti banyak diadopsi dalam merumuskan kurikulum PTAI. Suatu hal yang pasti, sejak 10 tahun terakhir, PTAI sudah menerapkan kurikulum yang mengintegrasikan antara ajaran normatif agama dengan aspek filosofis, historis, teoritis dan praksis. Gagasan tentang bangunan keilmuan teoantroposentris-integralistik, tentu saja, bukan semata-mata milik Abdullah, tetapi harus diakui bahwa dia lah yang paling banyak bersuara agar bangunan keilmuan semacam ini diterapkan dalam sistem pendidikan dan pengajaran di PTAI, terlebih lagi setelah adanya konversi beberapa IAIN menjadi UIN.

Pemikiran integralisasi keilmuan dari Amin Abdullah diperkirakan akan terus menggelinding ke dua arah; Pertama, pada pengembangan dan perbaikan kurikulum dan pendekatan dalam pengkajian Studi Agama di PTAI; dan kedua, tumbuhnya disiplin-disiplin baru yang digali dan dikembangkan dari sumber ajaran Islam dan tradisi masyarakat muslim. Perkiraaan ini didukung oleh kegigihan yang luar biasa dari Amin Abdullah dan sejumlah mantan mahasiswanya di PPS UIN Yogyakarta untuk mengembangkan gagasan ini di Indonesia. Jadi, sekalipun jabatan sebagai Rektor tidak lagi didudukinya sejak akhir 2010, namun pengaruh itu akan terus berjalan. Pemikiran tokoh pemikir ini akan terus mengalami perkembangan, terutama dalam perbaikan sistem pendidikan dan kurikulum di lingkungan PTAI.

\section{Penutup}

Jaring laba-laba keilmuan adalah sebuah peta konsep yang dirancang oleh Amin Abdullah yang menggambarkan bangunan keilmuan yang terbentuk dalam jaringan laba-laba. Peta konsep ini merupakan simpulan dari epistemologi keilmuan teoantropo-sentrikintegralistik yang mencoba memadukan antara wahyu, pemikiran, teori, dan isu-isu kontemporer. Pemikiran epistemologi ini tidak murni dari Amin Abdullah, melainkan diambil dari berbagai pemikiran sarjana sebelumnya, baik dari kalangan Islam maupun Barat.

Pemikiran tentang keilmuan teoantroposentrik-integralistik dari Amin Abdullah diawali dari kritik internal terhadap pola pemikiran umat Islam Indonesia, khususnya di kalangan PTAI. Amin Abdullah menyimpulkan bahwa ilmu-ilmu keislaman yang berkembang di PTAI masih bersifat fragmentaris, di mana masing-masing disiplin ilmu berdiri sendiri tanpa penjelasan bagaimana keterkaitannya dengan ilmu lain, terlebih lagi dengan isuisu kontemporer. Kelemahan lain ditemukan pada pendekatan yang digunakan yang masih terbatas dengan epistemologi indikasi serta eksplikasi ('ulûm al-bayân). Pendekatan ini cukup dominan sehingga melahirkan sikap keilmuan at-taqdis al-fikr al-islamy (penyakralan pemikiran Islam). Keadaan ini amat tidak relevan dengan kebutuhan umat Islam di era 
posmodernisme, karena itu diperlukan upaya membangun epistemologi yang bersifat integratif-interkonektif.

Epistemologi keilmuan teoantropo-sentrik-integralistik yang digagas oleh Amin Abdullah dimulai dari pengelompokan keilmuan yang dimulai dari Alquran dan Sunnah, kemudian 'Ulûm al-Dîn, al-Fikr al-Islâmy, dan Dirâsah al-Islâmiyyah. Keempat kategori keilmuan Islam ini dipetakan Amin Abdullah ke dalam empat lingkar lapis peta konsep spider web. Pada setiap lingkar lapis dituliskan nama-nama disiplin ilmu sesuai dengan tingkatannya. Epistemologi ini memadukan seluruh disiplin ilmu sosial dan keagamaan, karena di sinilah letak maksud teoantropo-sentrik-integralistik yang ditawarkan oleh Amin Abdullah.

\section{Pustaka Acuan}

Abdullah, Amin, "Integrasi Epistemologi Keilmuan Umum dan Agama dalam Sistem Sekolah dan Madrasah (Ke Arah Rumusan Baru Filsafat Pendidikan Islam yang Integralistik)", Disampaikan dalam "Roundtable discussion tentang Madrasah" diselenggarakan oleh Indonesian Institute for Civil Society (INCIS), Hotel Atlet Century Park Senayan, Jakarta, 22 Juli 2004; http://aminabd. wordpress.com/2010/04/30/integrasi-epistemologikeilmuan-umum-dan-agama-dalam-sistem-sekolah-dan-madrasah/; dikases 30 April 2010

Abdullah, Amin, "Mempertautkan 'Ulûm ad-Dîn, al-Fikr Al-Islamiy dan Dirasat Islam-iyyah: Sumbangan Keilmuan Islam Untuk Peradaban Global", http://aminabd. wordpress. com/ 2010/06/20/mempertautkan-ulum-al-diin-al-fikr-al-islamiy-dan-dirasatislamiyyah-sumbangan-keilmuan-islam-untuk-peradaban-global/; dikases 20 Juni 2010.

Abdullah, Amin, "Islam dan Modernisasi Pendidikan di Asia Tenggara: Dari Pola Pendekatan Dikotomis-atomistik kearah integratif-interdisiplinary", Makalah disampaikan dalam Konferensi Internasional Antar Bangsa Asia Tenggara, Universitas Gadjah Mada, Yogyakarta, 10 - 11 Desember 2004.

Abdullah, Amin, "Kajian Ilmu Kalam di IAIN", Artikel dalam www.ditpertais.net/ artikel/ amin01.asp.

Abdullah, Amin, "Pengembangan Metode Studi Islam dalam Perspektif Hermeneutika Sosial dan Budaya" dalam Jurnal Tarjih edisi ke-6, Juli 2003, (LPPI-UMY dan Majelis Tarjih \& PPI PP Muhammadiyah).

Abdullah, Amin, "Profil Kompetensi Akademik Lulusan Program Pascasarjana Perguruan Tinggi Agama Islam Dalam Era Masyarakat Berubah", Makalah yang disampaikan dalam Pertemuan dan Konsultasi Direktur Program Pasca Sarjana Perguruan Tinggi Agama Islam, Hotel Setiabudi, Jakarta, 24-25 Nopember 2002.

Abdullah, Amin, et al. Mencari Islam: Studi Islam dengan Berbagai Pendekatan. Yogyakarta: Tiarawacana, 2000. 
MIQOT Vol. XXXVIII No. 2 Juli-Desember 2014

Abdullah, Amin, Falsafah Kalam di Era Postmodernisme. Yogyakarta: Pustaka Pelajar, 1995.

Abdullah, Amin, Islamic Studies di Perguruan Tinggi, Pendekatan Integratif-Interkonektif. Yogyakarta: Pustaka Pelajar 2006.

Abdullah, Amin, Studi Agama; Normativitas atau Historisitas?. Yogyakarta: Pustaka Pelajar, 1996.

Al- Jabiri, Mohammed Abed. Post Tradisionalisme Islam. Yogyakarta: LKiS, 2000.

Arifin, "Pemikiran Amin Abdullah dan Jurgen Habermas", http://lucudanselaluceria. multiply.com/journal/item/5.

Azhar, Muhammad, "Wacana Agama dan Sains Dalam Perspektif Epistemologi Keilmuan Islam Kontemporer”, http://kangdim.wordpress.com/2009/05/; diakses 26 Mei 2009.

Dahlan, Moh., “Gagasan Islam Kontemporer Menurut M. Amin Abdullah”, http:// drdahlan. blogspot.com/2009/08/gagasan-islam-kontemporer-menurut-m.html, diakses 25 Agustus 2009.

Insawan, Husain, "Membedah Esai Pemikiran M. Amin Abdullah", http:// shautut-tarbiyah. wordpress.com/2009/11/20/membedah-esai-pemikiran-m-amin-abdul-lah-ed-212009/, diakses 20 November 2009.

Keputusan Bersama Menteri Pendidikan dan Menteri Agama Republik Indonesia Nomor: 1/0/SKB/2004; Nomor: ND/B.V/I/Hk.00.1/058/04 tentang Perubahan Bentuk Institut Agama Isam Negeri (IAIN) Sunan Kalijaga menjadi Universitas Islam Negeri (UIN) Sunan Kalijaga Yogyakarta ditandatangani di Departemen Pendidikan Nasional Jakarta pada tanggal 23 Januari 2004.

Kholil, Anwar, "Peta Konsep untuk Mempermudah Konsep Sulit dalam Pembela-jar-an", http://anwarholil.blogspot.com/2008/04/peta-konsep-untuk-mempermudahkonsep.html, diakses 7 April 2008.

Sularto, ST., "Amin Abdullah", http://www.uin-suka.info/ind/index2.php? option= com content \&do_pdf=1\&id=509, diakses 21 Juli 2010. 